\title{
変形性膝関節症の疫学
}

— 患者数推定と患者調査結果の検討 —

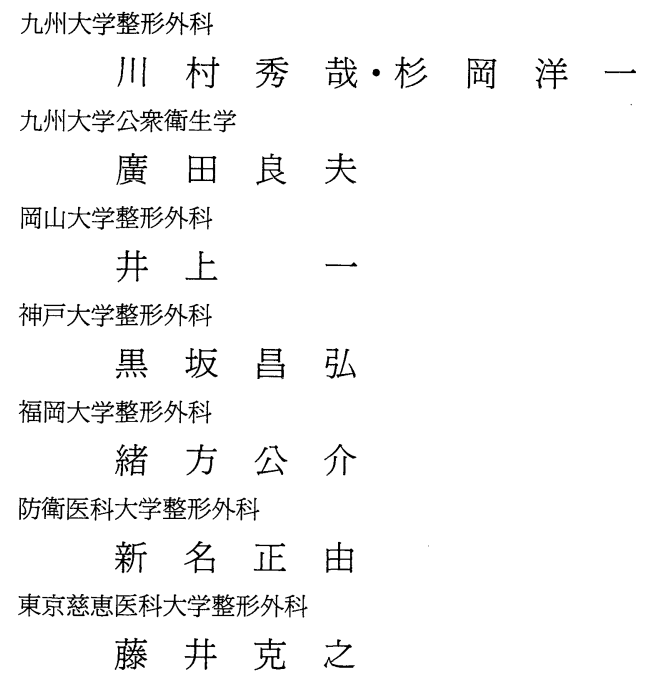

\section{Epidemiology of Osteoarthritis of the Knee} -Investigation of Incidence and the Results of a Case Studyby Hideya Kawamura, Yoichi Sugioka and Yoshio Hirota*

Department of Orthopaedic Surgery and * Department of Public Health,

Faculty of Medicine, Kyusyu University, Fukuoka

\section{Hajime Inoue}

Department of Orthopaedic Surgery, Faculty of Medicine,

Okayama University, Okayama

Masahiro Kurosaka

Department of Orthopaedic Surgery, Faculty of Medicine, Kobe University, Kobe

\section{Kosuke Ogata}

Department of Orthopaedic Surgery, Faculty of Medicine, Fukuoka University, Fukuoka

\section{Masayosi Shinmei}

Department of Orthopaedic Surgery, National Defense Medical School, Tokorozawa

\section{Katsuyuki Fujii}

Department of Orthopaedic Surgery, Jikei Medical School, Tokyo 
We measured the incidence of osteoarthritis of outpatients in six university and thirty-six general hospitals. In addition we performed a case study on osteoarthritis of the knee to investigate physical and other factors associated with severity of symptoms, uning a selfadministered questionnaire.

Investigation of the hospital statistics revealed that $7.6 \%$ of all orthopeadic patients had osteoarthritis of the knee, and $70 \%$ of these cases were females. Regarding age $97 \%$ of patients were over forty years of age, and 900,000 men and women were newly diagnosed with this disease every year.

Symptoms of this disease were more severe with increasing body weight and BMI(Body Mass Index) at the time of both initial examination and at forty years of age. Bluecollar workers presented with more severe symptoms than did other worgers.

Key words : Osteoarthritis of the knee (変形性膝関節症), Epidemiology (疫学), Case Study (患者調 查)

\section{はじめに}

老年者の関節疾患は高齢者の日常生活を著しく制約 し，QOL の低下や寝たきり老人となる要因の一つに なっている，この中でも変形性膝関節症は頻度の高い 疾患であるが，一般国民の関心や理解度は低く，しか もその病因や病態は十分には解明されていない. 本症 を早期に診断し, 進行を予防する措置を講じると共に, 治療法を確立させることは急務である，今回，医療機 関に扔ける統計調査によって本症患者発症状況の実態 の把握および患者調査による本症の病態の把握を目的 として研究を行った。

なお，患者調査の結果は第 21 回日本リウマチ・関 節外科学会にてその詳細を述べたので(3), 本稿では医 療機関における統計調査の結果を主として示す。

\section{方法}

1 ) 分担研究者所属の 5 大学病院（防衛医科大, 東京 慈恵医科大, 神戸大, 岡山大, 九州大) での 83 年 と 91 年に抢ける外来患者統計を集計し, 全科外来 新患における整形外科患者の割合, 整形外科新患に おける変形性膝関節症患者の割合を算出し, また, 変形性膝関節症患者の性差, 年齢構成を検討し, 整 形外科症患に招ける変形性膝関節症の位置付けを行っ た。

2 ) 分担研究者所属の 5 大学病院 (防衛医科大, 東京 慈恵医科大, 神戸大, 福岡大, 九州大）及びその関 連施設 36 , 計 41 の整形外科に扔ける 93 年 9 月（1
カ月間) の外来患者統計を集計し, 変形性関節症に おける変形性膝関節症の割合を算出した。この結果 と平成 2 年度厚生省患者調査の結果 (厚生省大臣官 房統計情報部 ${ }^{4}$ ) を基に本邦における本症患者発症 数を推定した.

\section{結果}

大学病院だけの調査では整形外科新患は全科での約 $10 \%$ を占め, 膝関節症は整形新患の内約 $4.5 \%$ を占め ていた（表 1). 83 年と 91 年の統計では大きな差はな かった。本症は女性が約 $70 \%$ を占め, 40 歳以上が全 体の約 $97 \%, 50$ 歳代以上で約 $87 \%$ を占め, 中高年者 に多い実態が示された（表 2)。

医療機関全 41 施設における調查（表 3）により変 形性関節症患者は整形外科新患の約 $12 \%$ を占めてお り, さらに変形性関節症に打ける変形性膝関節症患者 は約 $63 \%$ を占めていた（整形外科新患の $7.6 \%$ ). 平 成 2 年厚生省患者調查 ${ }^{4)}$ によると全国での 1 日におけ 方变形性関節症及びその類似症疾患患者は入院外来総 数で約 11 万人であり，1日の初診総数は 4700 人であっ た。このうち $63 \%$ が本症患者であるとすると 1 日の 入院外来総数は約 7 万人であり, 初診総数は 2975 人 で，1 年間（実日数 300 日）では新たに変形性膝関節 症患者が約 90 万人発生していると考えられた。

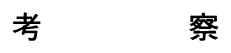

大学病院だけの調査では膝関節症は整形新患の内, 約 4.5\%を占めていたが，一般病院を含めた結果（表 
表 1 大学病院新患統計（全 5 施設）

\begin{tabular}{c|c|c}
\hline \hline & 1983 年 & 1991 年 \\
\hline 新 患 総 数 & 249488 & 303968 \\
整 形 新 患 総 数 & 26748 & 31080 \\
(整形/全科) & $10.7 \%$ & $10.2 \%$ \\
膝関節症新患数 & 1199 & 1299 \\
(膌関節症 / 整形総数) & $4.5 \%$ & $4.2 \%$ \\
男 性 & $27.4 \%$ & $28.4 \%$ \\
女 性 & $72.6 \%$ & $71.6 \%$ \\
男性：女性 & $1: 2.4$ & $1: 2.3$ \\
\hline
\end{tabular}

表 2 変形性膝関節症新患年歯分布 (大学病院全 5 施設)

\begin{tabular}{c|c|c}
\hline \hline & 1983 年 & 1991年 \\
\hline 30歳未満 & $9(0.8)$ & $8(0.6)$ \\
$30 \sim 39$ & $21(1.8)$ & $32(2.5)$ \\
$40 \sim 49$ & $144(12.0)$ & $113(8.7)$ \\
$50 \sim 59$ & $405(33.8)$ & $327(25.1)$ \\
$60 \sim 69$ & $369(30.8)$ & $471(36.3)$ \\
$70 \sim 79$ & $210(17.5)$ & $279(21.5)$ \\
80 歳以上 & $40(3.3)$ & $68(5.2)$ \\
\hline Total & $1198(\%)$ & $1299(\%)$ \\
\hline
\end{tabular}

表 3 多施設における93年9月（1力月間）患者統計 ( 5 大学病院とその関連施設 ; 41 施設)

\begin{tabular}{|c|c|c|c|c|}
\hline $\begin{array}{c}\text { 整形外科 } \\
\text { 病床数 }\end{array}$ & 施設数 & $\begin{array}{l}\text { 整形外科 } \\
\text { 新患総数 }\end{array}$ & $\begin{array}{l}\text { 変形性 } \\
\text { 関節症 }\end{array}$ & $\begin{array}{c}\text { 変形性 } \\
\text { 膝関節症 }\end{array}$ \\
\hline 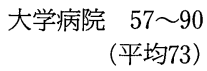 & 5 & 2621 & 237 & $\begin{array}{c}119 \\
(50.2 \%)\end{array}$ \\
\hline 関連病院 50未満 & 13 & 2774 & 490 & $\begin{array}{c}294 \\
(60.0 \%)\end{array}$ \\
\hline $50 \sim 100$ & 18 & 6050 & 663 & $\begin{array}{c}428 \\
(64.6 \%)\end{array}$ \\
\hline 100 以上 & 5 & 2344 & 275 & $\begin{array}{c}213 \\
(77.5 \%)\end{array}$ \\
\hline 計 & 41 & 13789 & 1665 & $\begin{array}{c}1054 \\
(63.3 \%)\end{array}$ \\
\hline
\end{tabular}

3）では $7.6 \%$ であ，施設数は少ないものの後者がよ り実情に即した結果ではないかと思われる，本症は女 性が約 3/4 近くを占め, 50 歳以上で約 $87 \%$ を占め, 一般外来にて我々医師が感じている本症の実態が改め て把握できた。 また，厚生省患者調査 ${ }^{4)}$ を利用するこ とにより，1日での本症の入院外来患者総数が約 7 万 人であり， 1 年間に新たに約 90 万人の患者が発症し ていると推測された。高齢化社会の進展に伴い, より
増加すると考えられ, 早期診断, 予防の指針を確立す ることが急務と考えられた。

患者調査は本疾患の発症状況や日常生活動作におけ る状況，等，多岐にわたる質問表を独自に作成し，岡 山，神戸，九州の 3 大学病院における過去 1 年間 $(90$ 年 9 月より 91 年 8 月) での変形性膝関節症新患 608 症例を対象として郵送法により検討した。この結果は 日本リウマチ・関節外科学会に投稿中であるが(3), 要 約すると以下のごとくである.

本症患者の初診時, 高率に認められた症状には和式 トイレの使用困難, 階段昇降困難, 椅子からの立ち上 がり動作の困難, 長時間の正座困難があった。これら の症状と様々な要因との間で統計処理を加え, その関 連を検討した結果，女性において初診時体重，BMI (Body Mass Index, 体重 $(\mathrm{kg}) /$ 身長 $(\mathrm{m})^{2}$ ) は症状の 重症度と有意に相関していた。 40 歳時の体重や BMI についても椅子からの立ち上がり動作などの項目で有 意な関連を認めた。男性においても同様の傾向が認め られたが, 女性ほど顕著な傾向は認めなかった。また, 女性において 20 歳以前のスポーツ実施状況と杖など の支持をしない歩行の能力について検討したところ， スポーツ頻度（1 週間での実施回数），スポーツ継続 年数，スポーツ種目をエネルギー代謝率に換算したス ポーツ強度との間に, 20 歳以前のスポーツ経験のあっ た患者ほど歩行障害の程度が軽い傾向を認めた，初診 時より以前の職業についての検討で職業をブルーカラー とそれ以外の労働に分けて検討したところ，階段昇降 での支持の必要性や支持なしでの歩行能力においてブ ルーカラー労働者の方が歩行能力が劣っている傾向を 認めた.これらの結果により, 本症の発症, 進展にお いて肥満の度合いが強く関与していることが示された。 また，スポーツを行うことにより基礎体力が向上し， 初診時症状が軽度となったと推察され, 職業の検討に より過度な労働による関節症の進行が示唆された。

これらの結果は欧米にて従来より指摘されていたこ とである115)6) が，この結果を踏まえ，今後住民調査を 企画実施し, 変形性膝関節症発症の危険因子の分析や 実情の把握に役立てる予定である。変形性膝関節症の 手術治療に関しては関節鏡手術や高位脛骨骨切り術2), 人工関節手術など完成されつつあるが，これら疫学的 研究により本症の早期診断, 予防の指針の確立が容易 になると思われる。 
結 語

変形性膝関節症患者の病院統計調查および厚生省患 者調査の結果により，本症は中高年の女性に多く，毎 年約 90 万人もの患者が新たに発症している事実が判 明した。

患者調査により初診時および 40 歳時の体重, BMI を指標とする肥満の程度と初診時の様々な症状の重症 度とは強く相関していた。

(なお本研究は平成 4 年及び 5 年度の厚生科学研究補助金 (長寿科学総合研究事業) より助成を受けた。)

\section{参 考 文 献}

1) Danielsson, L., Hernborg, J. : Morbidity and mortality of osteoarthritis of the knee (Gonarthrosis) in Malmo, Sweden. Clin Orthop, $69: 224-226,1970$

2) 川村秀哉ら：変形性膝関節症に対する Inetrlocking Wedge Osteotomy - 術後 10 年以上経過例の検討一. 関 節外科, $12: 200-207,1993$

3）川村秀哉ら：変形性膝関節症の病態一患者調查結果 の検討一. 日本リウマチ・関節外科学会雑誌，投稿中

4）厚生省大臣官房統計情報部編：平成 2 年患者調査 (全国編), 財団法人厚生統計協会, 東京：62-175, 1992

5) Leach, R. E. et al. : Obesity : Its relationship to osteoarthritis of the knee. Clin Orthop, $93: 271-273$, 1973

6) Lindberg, H., Montgomery, F. : Heavy labor and the occurrence of gonarthrosis. Clin Orthop, $214: 235$ 236, 1987 